\title{
Proposed Lease Accounting For Lessees
}

\author{
Stuart Shough, University of South Carolina Upstate, USA
}

\begin{abstract}
On August 17, 2010, the Financial Accounting Standards Board and the International Accounting Standards Board jointly issued exposure drafts proposing a new accounting model for leases. This paper explains how a lessee would account for leases under this proposal.
\end{abstract}

Keywords: FASB proposed lease accounting

\section{INTRODUCTION}

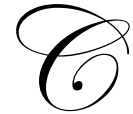

urrent procedure allows for certain assets to be defined by the method of financing. Many believe that an asset should be defined by its use; if it is a tool of production, it is an asset and should be so reported. A tool acquired under an operating lease currently is expensed and is not recognized for its functional reality, an asset.

Existing lease accounting standards require lessees to classify their lease contracts as either finance (capital) or operating leases. If a lease is classified as a finance lease, assets (and liabilities) are recognized in its statement of financial position. For an operating lease, the lessee simply recognizes lease payments as an expense over the lease term.

This split into finance and operating leases has given rise to a number of problems. Users complain that financial statements do not clearly depict the effects of operating leases. Many users think that operating leases give rise to assets and liabilities; therefore, they think lessees should recognize operating leases in their statement of financial position. Operating and finance leases are accounted for very differently, which reduces comparability for users. Users also complain that the standards provide opportunities to structure transactions so as to achieve a particular lease classification. Preparers and auditors have criticized the existing model for its complexity.

On August 17, 2010, the Financial Accounting Standards Board (FASB) issued an exposure draft (ED), Leases, which creates a new accounting model for both lessees and lessors and will eliminate operating leases. The ED does not specify an effective date, but the board expects to issue a final standard in June 2011. This paper describes the accounting treatment under this ED.

\section{NEW MODEL}

Lessees would use the 'right-of-use' model. This model states that the lessee's right to use the leased asset represents an asset and the lessee would record an intangible asset representing its right to use the leased asset for the lease term and a liability for the obligation to make lease payments.

The lessee would use its own incremental borrowing rate in determining the lease liability. The lease liability would be measured based on estimates of:

- $\quad$ The lease term

- $\quad$ Contingent rentals

- $\quad$ Expected payments under term option penalties and

- $\quad$ Residual value guarantees 
The right-of-use asset would be amortized over the shorter of the lease term or its useful life. Lease payments would be allocated between interest expense and a reduction of the lease liability using the effective interest method. Lease payments would no longer be recognized as rental expense under the straight-line method.

For leases that have been classified as operating leases, rent expense will be replaced with amortization expense and interest expense.

Assets and liabilities would be reassessed each reporting period when changes in facts or circumstances indicate that there would be a significant change in those assets or liabilities.

Table 1 illustrates a simple lease for the lessee.

Table 1

\begin{tabular}{|lc|}
\hline \multicolumn{1}{|c|}{ Proposed Lessee Accounting Example } \\
\hline Lease term & 3 years \\
$\begin{array}{l}\text { Annual lease payments } \\
\quad \text { There are no contingent rentals, residual } \\
\text { value guarantee or term option penalities }\end{array}$ & $\$ 8,000$ \\
Lessee's incremental borrowing rate & $8 \%$ \\
Lease liability (present value of the lease payments) & $\$ 20,617$ \\
Right-of-use asset (same as lease liability) & $\$ 20,617$ \\
\hline
\end{tabular}

Table 2 shows the entries that the lessee would record for the inception of the lease and at the end of each year of the lease term.

Table 3 compares the results of the example in the income statement between the proposed accounting and an operating lease using existing accounting standards.

\section{CONSEQUENCES}

There would initially be an increase in assets and liabilities on the balance sheet for all leases previously accounted for as an operating lease. As for the income statement, the straight-line recognition of rental expense for operating leases would be replaced by the effective interest method's accelerated recognition of interest expense, together with amortization of the right-of-use asset.

Total lease-related expense will be front-end loaded causing net income to be lower in the early years of the lease term. The expenses would be greater than the lease payments in the early years and lower than the lease payments in the later years.

How this could affect financial leverage ratios:

- Assuming that total debt is less than total assets, the debt ratio would increase if assets and liabilities are increased by the same amount

- $\quad$ The debt-to-equity ratio would increase since total debt would increase and total equity would decrease.

- $\quad$ Since EBIT will decrease and interest charges will increase, the times interest earned ratio will decrease. 
How this could affect profitability ratios:

- $\quad$ Return on assets would decrease due to a decrease in net income and an increase in total assets.

- Return on equity would decrease assuming net income and shareholder equity decrease by an equal amount.

Table 2

\section{Journal Entries for the Proposed Lessee Accounting}

\section{Entry at the inception of the lease}

Right-of-use asset

20,617

Lease liability

20,617

Entries at the end of year 1

Lease liability

6,351

Interest expense

1,649

Cash

8,000

Amortization expense

6,872

Right-of-use asset

6,872

Straight-line amortization $(20,617 \div 3)$

Entries at the end of year 2

Lease liability

6,859

Interest expense

1,141

Cash

8,000

Amortization expense

6,872

Right-of-use asset

6,872

Entries at the end of year 3

Lease liability

7,407

Interest expense

593

Cash

8,000

Amortization expense

6,873

Right-of-use asset

6,873

Table 3

\begin{tabular}{|c|c|c|c|c|c|c|c|}
\hline \multicolumn{8}{|c|}{ Income Statement - Proposed vs Operating } \\
\hline Proposed lessee accounting & & ear 1 & & Year 2 & & ear 3 & Total \\
\hline Amortization of the right-of-use asset & $\$$ & 6,872 & $\$$ & 6,872 & $\$$ & 6,873 & $\$ 20,617$ \\
\hline \multirow[t]{2}{*}{ Interest expense } & & 1,649 & & 1,141 & & 593 & 3,383 \\
\hline & $\$$ & 8,521 & $\$$ & 8,013 & $\$$ & 7,466 & $\$ 24,000$ \\
\hline \multicolumn{8}{|l|}{ Existing operating lease accounting } \\
\hline Lease expense & $\$$ & 8,000 & $\$$ & 8,000 & $\$$ & 8,000 & $\$ 24,000$ \\
\hline
\end{tabular}




\section{SCOPE}

The guidance applies to all leases except leases of intangible assets, leases to explore for or use minerals, oil, natural gas and similar non-regenerative resources and leases of biological assets.

The exposure draft does not apply to contracts that represent the purchase of an asset. A lease represents a purchase if at the end of the lease term the lessor transfers control of the asset and all but a trivial amount of the risks and benefits associated with the asset to the lessee. This is determined at the inception of the lease and is not subsequently reassessed.

A lease contract normally transfers control of an asset when the contract automatically transfers title to the asset to the lessee at the end of the lease term or includes a bargain purchase option.

The transfer of title of the asset would not be sufficient for a lessee to treat the lease as a purchase since all but a trivial amount of the risks and benefits must also be transferred to the lessee, but what constitutes a trivial amount? The exposure draft does not provide any specific guidance.

\section{SHORT-TERM LEASES}

The exposure draft provides simplified requirements to mitigate concerns about the cost of accounting for short-term leases. At the inception of a lease and subsequently, a lessee may elect to measure a short-term lease liability at the undiscounted amount of the lease payments and the right-of-use asset at the undiscounted amount of the lease payments plus initial direct costs. The lessee would just recognize lease payments in the income statement over the lease term.

\section{THE LEASE TERM}

The lease term is the longest possible term that is more than likely than not to occur. Leases that contain renewal options or options for early termination, the lessee will have to estimate the probability of occurrence for each possible term, for example, a lessee enters into a non-cancellable 5-year lease with two 5-year options to renew. The lessee assigns the following probabilities to each of the potential terms:

- $\quad$ A 40 percent probability of a 5-year term

- A 30 percent probability of a 10 -year term

- A 30 percent probability of a 15 -year term

The term will be at least 5 years. There is a 60 percent chance of a 10-year term or longer, but only a 30 percent chance of a 15-year term. The longest possible term more likely than not to occur is 10 years; therefore, the lease term is 10 years. This is clearly a subjective process.

Some considerations in assessing the probability of each possible lease term:

- $\quad$ Contractual factors such as termination penalties and the level of lease payment, for example, bargain renewal rates.

- $\quad$ Noncontractual factors such as the significant leasehold improvements.

- $\quad$ Business factors such as whether the leased asset is specialized for the lessee.

- $\quad$ Other lessee-specific factors such as past experience and the lessee's intentions.

\section{DETERMINING THE PRESENT VALUE OF LEASE PAYMENTS}

The lease liability would be measured based on estimates of:

- $\quad$ The lease term 
- Contingent rentals

- $\quad$ Expected payments under term option penalties and

- $\quad$ Residual value guarantees

The present value of the lease payments will be determined on the basis of expected outcome. Estimating expected outcome involves:

- $\quad$ Identifying each reasonably possible outcome.

- $\quad$ Estimating the amount and timing of the cash flows for each reasonably possible outcome.

- $\quad$ Determining the present value of those cash flows.

- $\quad$ Estimating the probability of each outcome.

EXAMPLE OF DETERMINING LEASE PAYMENTS USING EXPECTED OUTCOME

The ABC Co. entered into a lease for retail space at a shopping mall. The lease is noncancelable for 10 years with two 5-year renewals. The annual lease payment is $\$ 1$ million per year plus an additional contingent rent of 2 percent of sales per year. The lease does not include a purchase option or residual value guarantee. The ABC Co.'s incremental borrowing rate is 8 percent.

The first step is to determine the lease term. The company determined the probabilities of each possible lease term based on contractual factors, the existence of leasehold improvements, and it past history of renewals.

The company assigned the probabilities to each of the potential terms (Table 4):

Table 4

\begin{tabular}{lccc}
\hline & Two & One & No \\
Renewals & $\underline{\text { Renewal }}$ & $\frac{\underline{\text { Renewal }}}{10 \text { years }}$ \\
Lease term & 20 years & 15 years & $30 \%$ \\
Probability & $40 \%$ & $30 \%$ & $100 \%$ \\
Cumulative probability & $40 \%$ & $70 \%$ & 300 \\
\hline
\end{tabular}

The term will be at least 10 years. There is a 70 percent chance of a 15 -year term or longer, but only a 40 percent chance of a 20 -year term. The longest possible term more likely than not to occur is 15 years, therefore, the lease term is 15 years.

The next step is to determine the lease obligation over the expected lease term. This will be the present value of the annual lease payments and the expected outcome of the contingent rentals (Table 5). The exposure draft defines the expected outcome as is the present value of the probability-weighted average of the cash flows for a reasonable number of outcomes.

Based on the expected outcomes, the total amount of the lease obligation would be $\$ 9,701,948$, consisting of $\$ 1,142,469$ of contingent rentals and $\$ 8,559,479$ present value of the annual lease payments, as shown in Table 6 . The cost of the right-of-use asset equals the lease obligation.

Table 7 reflects the journal entry that ABC Co. would make at the inception of the lease to record the rightof-use asset and the lease obligation.

If the actual sales for the first year are $\$ 6,673,700$, the company will make the journal entry shown in Table 8 to record the interest method amortization of the lease obligation. The right-of-use asset is amortized on a straightline method. If sales were $\$ 6,673,700$ each year for the next 15 years, the amortization of the lease obligation would be reduced to zero with a rounding adjustment of $\$ 5$ as shown in Schedule 2. 
Table 5

\begin{tabular}{|c|c|c|c|c|c|c|}
\hline \multicolumn{7}{|c|}{ Expected Contingent Rentals--See Schedule 1} \\
\hline & $\begin{array}{c}\text { Outcome } \\
1 \\
\text { Constant } \\
\text { Sales }\end{array}$ & $\begin{array}{c}\text { Outcome } \\
2 \\
\text { Sales Growth } \\
3 \% \text { per year }\end{array}$ & $\begin{array}{c}\text { Outcome } \\
3 \\
\text { Sales Growth } \\
5 \% \text { per year }\end{array}$ & $\begin{array}{c}\text { Outcome } \\
4 \\
\text { Sales Decline } \\
2 \% \text { per year }\end{array}$ & & Total \\
\hline \multicolumn{7}{|l|}{$\begin{array}{l}\text { Total sales over } 15 \text { years, } \\
\text { assuming } \$ 6 \mathrm{M} \text { in yr } 1\end{array}$} \\
\hline plus growth/decline & $\$ 90,000,000$ & $\$ 111,593,483$ & $\$ 129,471,382$ & $\$ 78,429,269$ & & \\
\hline Total contingent rent* & $1,800,000$ & $2,231,870$ & $2,589,428$ & $1,568,585$ & & \\
\hline PV of total contigent rent & $1,027,137$ & $1,221,273$ & $1,378,541$ & 920,607 & & \\
\hline Probability & $45 \%$ & $35 \%$ & $15 \%$ & $5 \%$ & & \\
\hline \multirow{2}{*}{$\begin{array}{l}\text { PV of the probability-weighted } \\
\text { average of the cash flows }\end{array}$} & & & & & & \\
\hline & 462,212 & 427,446 & 206,781 & 46,030 & $\$$ & $1,142,469$ \\
\hline
\end{tabular}

Schedule 1 Worsheet for Contingent Rentals

\begin{tabular}{|c|c|c|c|c|c|}
\hline Growth/Decline & 0.03 & & & Beginning of the & \\
\hline Year & Sales & Growth/Decline & & $\begin{array}{c}\text { Year Sales Times } \\
\text { Contigent Rate }\end{array}$ & $=\mathrm{NPV}$ formula \\
\hline 1 & $6,000,000$ & 180,000 & $6,180,000$ & 120,000 & $1,221,273$ \\
\hline 2 & $6,180,000$ & 185,400 & $6,365,400$ & 123,600 & \\
\hline 3 & $6,365,400$ & 190,962 & $6,556,362$ & 127,308 & \\
\hline 4 & $6,556,362$ & 196,691 & $6,753,053$ & 131,127 & \\
\hline 5 & $6,753,053$ & 202,592 & $6,955,644$ & 135,061 & \\
\hline 6 & $6,955,644$ & 208,669 & $7,164,314$ & 139,113 & \\
\hline 7 & $7,164,314$ & 214,929 & $7,379,243$ & 143,286 & \\
\hline 8 & $7,379,243$ & 221,377 & $7,600,620$ & 147,585 & \\
\hline 9 & $7,600,620$ & 228,019 & $7,828,639$ & 152,012 & \\
\hline 10 & $7,828,639$ & 234,859 & $8,063,498$ & 156,573 & \\
\hline 11 & $8,063,498$ & 241,905 & $8,305,403$ & 161,270 & \\
\hline 12 & $8,305,403$ & 249,162 & $8,554,565$ & 166,108 & \\
\hline 13 & $8,554,565$ & 256,637 & $8,811,202$ & 171,091 & \\
\hline 14 & $8,811,202$ & 264,336 & $9,075,538$ & 176,224 & \\
\hline 15 & $9,075,538$ & 272,266 & $9,347,804$ & 181,511 & \\
\hline Total sales over the 15 years & $111,593,483$ & & & $2,231,870$ & $1,221,273$ \\
\hline based on \% growth/decline & & & & Total Contingent & Present Value \\
\hline & & & & Rent based on & Of Contingent \\
\hline & & & & Growth/Decline & Rentals \\
\hline
\end{tabular}

Table 6

\begin{tabular}{|l|r|}
\hline \multicolumn{2}{|c|}{ Amount of Lease Obligation And Right-of-Use Asset } \\
\hline Contingent rentals & $\$ 1,142,469$ \\
\hline Annual leasse payments (PV of \$1M per year for 15 years) & $8,559,479$ \\
\hline Total lease obligation and right-of-use asset & $\$ 9,701,948$ \\
\hline
\end{tabular}


Table 7

\begin{tabular}{|cc|}
\hline \multicolumn{2}{|c|}{ Journal Entry at the Beginning of Year 1} \\
\hline $\begin{array}{c}\text { Right-to-use asset } \\
\text { Lease obligation }\end{array}$ & $9,701,948$ \\
\hline
\end{tabular}

Table 8

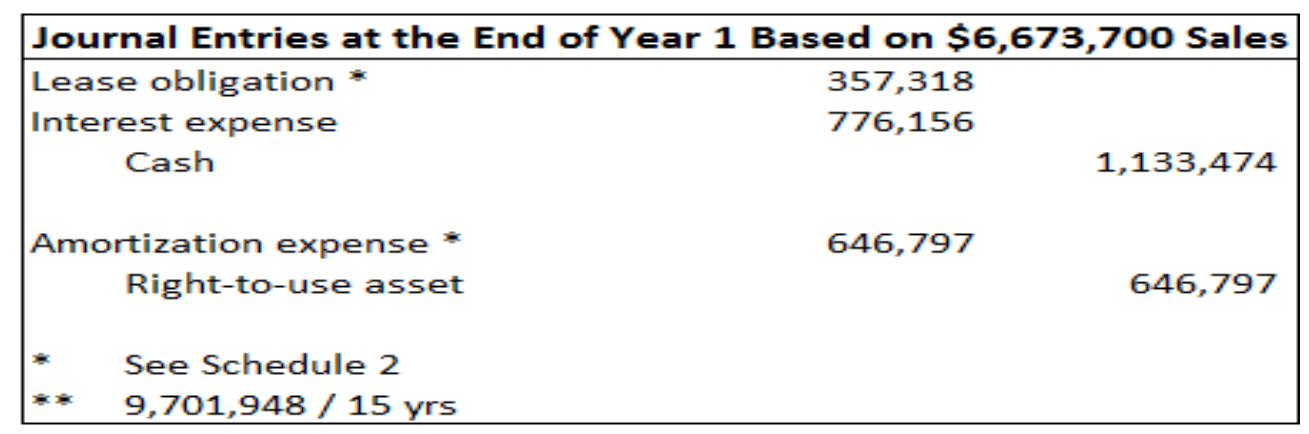

Schedule 2

\begin{tabular}{|c|c|c|c|c|c|c|}
\hline \multicolumn{7}{|c|}{ Amortization of Lease Obligation } \\
\hline \multirow[b]{2}{*}{ Year } & \multirow{2}{*}{$\begin{array}{l}\text { Beginning } \\
\text { Liability } \\
\text { Balance }\end{array}$} & \multicolumn{2}{|c|}{$\$ 1,000,000$ Annual Payment } & \multirow{2}{*}{$\begin{array}{c}2 \% \text { Contingent } \\
\text { Rent on } \\
\$ 6,673,700 *\end{array}$} & \multirow{2}{*}{$\begin{array}{c}\text { Total } \\
\text { Liability } \\
\text { Reduction }\end{array}$} & \multirow{2}{*}{$\begin{array}{l}\text { Ending } \\
\text { Liability } \\
\text { Balance }\end{array}$} \\
\hline & & $\begin{array}{c}8 \% \\
\text { Interest Expense }\end{array}$ & $\begin{array}{l}\text { Liability } \\
\text { Reduction }\end{array}$ & & & \\
\hline 1 & $9,701,948$ & 776,156 & 223,844 & 133,474 & 357,318 & $9,344,630$ \\
\hline 2 & $9,344,630$ & 747,570 & 252,430 & 133,474 & 385,904 & $8,958,726$ \\
\hline 3 & $8,958,726$ & 716,698 & 283,302 & 133,474 & 416,776 & $8,541,950$ \\
\hline 4 & $8,541,950$ & 683,356 & 316,644 & 133,474 & 450,118 & $8,091,832$ \\
\hline 5 & $8,091,832$ & 647,347 & 352,653 & 133,474 & 486,127 & $7,605,705$ \\
\hline 6 & $7,605,705$ & 608,456 & 391,544 & 133,474 & 525,018 & $7,080,687$ \\
\hline 7 & $7,080,687$ & 566,455 & 433,545 & 133,474 & 567,019 & $6,513,668$ \\
\hline 8 & $6,513,668$ & 521,093 & 478,907 & 133,474 & 612,381 & $5,901,288$ \\
\hline 9 & $5,901,288$ & 472,103 & 527,897 & 133,474 & 661,371 & $5,239,917$ \\
\hline 10 & $5,239,917$ & 419,193 & 580,807 & 133,474 & 714,281 & $4,525,636$ \\
\hline 11 & $4,525,636$ & 362,051 & 637,949 & 133,474 & 771,423 & $3,754,213$ \\
\hline 12 & $3,754,213$ & 300,337 & 699,663 & 133,474 & 833,137 & $2,921,076$ \\
\hline 13 & $2,921,076$ & 233,686 & 766,314 & 133,474 & 899,788 & $2,021,288$ \\
\hline 14 & $2,021,288$ & 161,703 & 838,297 & 133,474 & 971,771 & $1,049,517$ \\
\hline 15 & $1,049,517$ & 83,961 & 916,039 & 133,474 & $1,049,513$ & 5 \\
\hline \multirow{2}{*}{\multicolumn{2}{|c|}{ Totals }} & \multicolumn{2}{|c|}{$7,300,167 \quad 7,699,833$} & \multicolumn{2}{|r|}{$9,701,943$} & \\
\hline & & \multicolumn{2}{|c|}{$\$ 15,000,000$ Lease Payments } & & \$5 Rounding & \\
\hline * & $133,474 / .02=$ & $\$ 6,673,700$ & 3,474 deter & ined by trial anc & error & \\
\hline
\end{tabular}

Naturally, sales will not equal $\$ 6,673,700$ each year. Suppose sales at the end of year 1 are $\$ 7,000,000$. The exposure draft does not provide specific guidance as the account(s) to use in this case. As one possible solution, ABC Co. could use another contingent expense/income account. This account would be debited when sales are above $\$ 6,673,700$ and would be credited when sales are below that amount, and the cash account would be adjusted accordingly. This account would serve as a red flag for management. A large balance, debit or credit, could alert management that a reassessment of the expected contingent rentals might be needed. Table 9 reflects the journal entries based on this approach. 
Table 9

\begin{tabular}{|c|c|c|}
\hline Journal Entries at the End of Year & sed on $\$ 7, c$ & ,o00 Sales \\
\hline Lease obligation & 357,318 & \\
\hline Interest expense & 776,156 & \\
\hline Other contingent expense/income* & 6,526 & \\
\hline Cash & & $1,140,000$ \\
\hline Amortization expense & 646,797 & \\
\hline Right-to-use asset & & 646,797 \\
\hline Based on an additional $\$ 326,3$ & es times $2 \%$ & \\
\hline
\end{tabular}

A comparison between the proposed standard and the current standard for an operating lease is shown in Tables 10 and 11. The sales for the year are \$7,000,000. The expenses are front-end loaded for the proposed standard and are therefore higher in the early years than under the current standard causing net income to be less upon adoption of a final standard.

Table 10

\begin{tabular}{|l|r|}
\hline Income statement Proposed Standard & Year 1 \\
\hline Amortization of the right-of-use asset & $\$ 646,797$ \\
Interest expense & 776,156 \\
Other contingent expense/income & 6,526 \\
\cline { 2 - 2 } Total income statement expense & $\$ 1,429,479$ \\
\hline
\end{tabular}

Table 11

\begin{tabular}{|l|r|}
\hline Income statement Current Standard & \multicolumn{1}{|c|}{ Year 1 } \\
\hline Rent expense & $\$ 1,000,000$ \\
Contingent rent & 140,000 \\
\cline { 2 - 2 } Total income statement expense & $\$ 1,140,000$ \\
\hline
\end{tabular}

\section{LEASE INCENTIVES}

The exposure draft does not address the following lease incentives:

- $\quad$ Payments by the lessor to the lessee to enter into the lease

- $\quad$ Allowances provided by a lessor to a lessee for tenant improvements

You should expect guidance on these topics when the final standard is issued.

\section{AUTHOR INFORMATION}

Stuart Shough has worked in the private sector for 12 years and has taught accounting for 27 years. He is currently Senior Instructor at the George Dean Johnson, Jr. College of Business and Economics at the University of South Carolina Upstate.

\section{REFERENCES}

Available from author 